\title{
Research Libraries and Scientific Publishers
}

T N WHAT WAys can college and research 1 libraries and scientific publishers, as typified by the American Chemical Society, cooperate to best advantage in our common cause-the widest and most rapid dissemination of scientific knowledge? This is an extremely complex question, and needs far more time for adequate discussion than we have at this time. Therefore I shall limit my remarks to two matters which are of major concern to all of us.

I shall consider first the changes in reading and subscription habits which are drastically increasing the operating costs of libraries and forcing subscription prices upward. Then I shall comment briefly upon the matter of unrestricted reproduction of copyrighted material. Finally, by using Chemical $A b$ stracts as a case history, I shall illustrate how these two things are affecting critically the present and future course of this publication.

A phenomenal growth in scientific publishing has occurred since World War II. Perhaps this is most dramatically demonstrated by the growth of Chemical Abstracts. In 1947 it published 30,000 abstracts of papers and in 1958 it published more than 95,000. This indicates that there has been more than a threefold increase in chemical papers published in primary journals during that period.

Mr. Belknap is Business Manager, American Chemical Society. This paper was presented as a talk at the Washington Conference's meeting of ACRL's Advisory Committee on Cooperation with Educational and Professional Organizations, June 24.
Mere volume of material has increased costs. Inflation has also. Unfortunately rising expense has not been accompanied by increased numbers of subscribers to share the new costs. For example, the Journal of the American Chemical Society in 1933 had 17,500 subscriptions, but in 1958 only 15,600 . The inevitable result has been that each subscriber pays much more for this journal than he did ten years ago.

For a number of years both membership and the number of subscriptions to Society journals increased, although not in parallel, and helped to hold prices relatively stable. Now this is no longer true. To a considerable degree the growth in library services is responsible for the decreases in circulation. Extended library services make it largely unnecessary for many scientists to subscribe personally. The day of the individual extensive private library is nearly gone. For example W. Albert Noyes, editor of the Journal of the American Chemical Society, recalls the day when his father's library was the library of the chemistry department at the University of Illinois. Now that institution has its own departmental library paid for from university funds.

Higher prices have driven some subscribers away although member subscriptions to society journals still are remarkably cheap. For example a member can buy Industrial and Engineering Chemistry for only $\$ 4.50$ and Chemical $A b$ stracts for the fantastically low price of $\$ 20$. What seems to have had a greater influence in reducing subscriptions is that centralized searching services act as an inhibitor on personal subscriptions and on the number of departmental subscriptions which might be en- 
tered. This hurts subscription sales and tends toward further increases in subscription prices. Regardless of how many persons are served by one copy someone must pay original, fixed costs and these are high.

Whether we produce one copy or 15,000 copies of the Journal of the American Chemical Society someone must pay the fixed costs of over $\$ 245,000$ for editorial production, copy preparation, and setting the articles in type for printing the first copy. As matters now stand, you can subscribe to this journal for $\$ 30, \$ 15.66$ of which are fixed costs. If all our member subscribers were lost, however, this journal would cost you $\$ 95$. If, on the other hand, circulation could be doubled, each library subscription would cost only $\$ 15$ to $\$ 20$ and more than twice as many persons would be served.

We believe that every scientist should subscribe to some scientific or technical periodical. Not only does he protect his investment in his scientific training but his subscription helps to hold costs down for all classes of subscribers. We believe that you can help us and yourselves if you will promote the idea of copies for personal use of at least one or two journals for every scientist or student of science who uses your service.

Frequently ideas obtained from general reading of scientific journals will lead to the recognition of the application of findings from an apparently unrelated field. Systematic searches by others could fail to uncover these nuggets.

Another library practice which is becoming increasingly widespread is the custom of more or less unrestricted photocopying of parts of journals for interoffice circulation and other use. If carried to a degree which reduces subscription orders, the practice will end by hurting both of us.

Certainly there is no objection to the making of a single copy of an article from a copyrighted publication for in- clusion in a departmental report. Upon request the ACS always has been willing to grant such permission. Of late, however, the practice has grown to the stage where we now definitely can point to lost subscriptions. Fortunately, both your profession and our own are seeking a practical way to provide this service in a manner equitable for all. One service already provided by the ACS is the right to reproduce material from CA for a fee.

What perhaps is not understood by libraries which engage in this practice is the income lost to publishers, not only in subscription revenue but in income from the sale of back numbers and single copies of current issues, income which helps to hold down subscription prices.

The ACS this year will invest over six million dollars in the production and distribution of its serial publications. Every act-and photocopying is onewhich serves to decrease circulation to our journals has just one effect. Those libraries and others which must have the journals to exist must somehow pay that six million dollars if these journals are to continue. That means every subscriber pays more than he would if many individuals subscribed.

Also, ACS maintains back issue stocks of nearly two million numbers. These cost us money to produce and they cost us money to house. Much of this investment never will be recovered if libraries continue to photocopy for individuals and in other cases where back issues should be purchased. Our operation must break even. Every source of subsidiary income of which you deprive us increases your subscription expense.

Let us examine Chemical Abstracts in the light of the comments made above. This journal is probably more widely available and more widely used in technical libraries than any other scientific publication.

(Continued on page 382) 


\section{Research Libraries and Scientific Publishers}

(Continued from page 354)

Despite the fact that it costs the ACS member only $\$ 20$ per year, member circulation has dropped from 22,675 in 1949 to 17,301 in 1958. Why? Apparently because libraries have made Chemical Abstracts and information from Chemical Abstracts so easily available. There is no urgency felt by the individual scientist to subscribe to this publication. This is a rather disheartening observation to make about our members but it does seem to be valid.

With the steady decline in number of subscriptions and the increase in material published it has become necessary to charge more and more for Chemical Abstracts. Prices now are $\$ 20$ to members, $\$ 80$ to colleges and universities, and $\$ 350$ to all others. For 1960-and you are among the first to know-these prices will increase to $\$ 32, \$ 150$, and $\$ 570$. The two higher categories of prices are those paid by libraries.

How could these prices be reduced or held stable? From the results of research, for one. The ACS already has an extensive program in progess. We hope thereby to reduce some expenses and add some special services, for a fee. By increasing numbers of subscriptions is a second way; each subscriber then pays less in fixed charges. Finally-and strangely enough-by not photocopying material from this publication for distribution unless you pay for the right to do so. Based on evidence on hand we have calculated that if the material reproduced from Chemical Abstracts were all paid for at the fees we charge for this service, and if libraries took advantage of this special service to compile bulletins consisting of pertinent abstracts for their own organizations, the price of every nonmember subscriber could be reduced by $\$ 50$ to $\$ 75$ and perhaps more. Furthermore we believe that adoption of this plan would save library staffs much of the time now spent in making their own abstracts.

The ACS charter sets forth as one of the primary objectives of the Society the promoting of scientific interest and inquiry through its publication program. We want to make our journals as useful as possible and also to do all in our power to see that they are universally available. To a large extent you are agents in providing availability. We earnestly desire to work with you.

\section{New Periodicals of 1959-Part I}

\section{(Continued from page 368)}

linzona, Switzerland. v.1, no.1, January/February 1959. Bimonthly. Fr.18.

Science Information News. National Science Foundation, Washington 25. v.1, no.1, February/March 1959. Bimonthly. \$1.25.

SIAM Review. Society for Industrial and Applied Mathematics. Box 7541, Philadelphia. v.1, no.1, January 1959. Semiannual. $\$ 5$.
Technical Education. Evans Brothers, Ltd., Montague House, Russell Square, London, WC 1. v.1, no.1, February 1959. Frequency not given. Price not given.

Technometrics. J. Stuart Hunter, 167 Nassau Street, Princeton, N.J. v.l, no.l. February 1959. Quarterly. \$8.

Tropical Science. H.M. Stationery Office, London. v.1, no.1, 1959. Quarterly. 26s. 